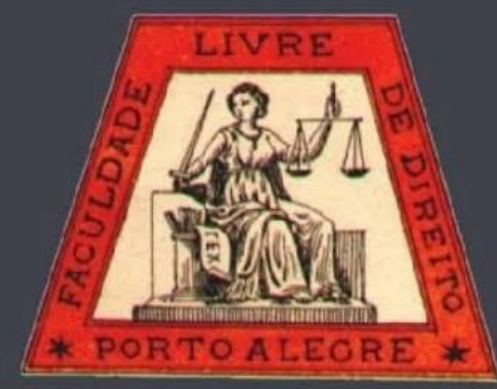

Observações preliminares sobre o acordo de não persecução penal: da inconstitucionalidade à inconsistência argumentativa

Preliminary comments on the Brazilian agreement of no criminal prosecution: from its unconstitutionality to its argumentative inconsistency

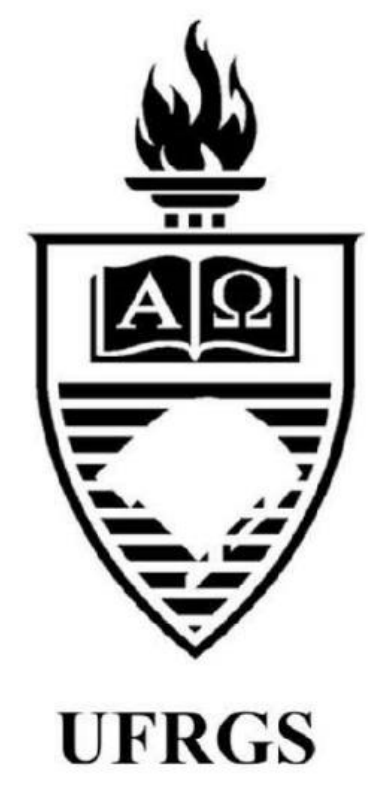

Mauro Fonseca Andrade

Universidade Federal do Rio Grande do Sul

Rodrigo da Silva Brandalise

Ministério Público do Rio Grande do Sul 


\title{
Observações preliminares sobre o acordo de não persecução penal: da inconstitucionalidade à inconsistência argumentativa
}

\author{
Preliminary comments on the Brazilian agreement of no criminal prosecution: from its \\ unconstitutionality to its argumentative inconsistency
}

\author{
Mauro Fonseca Andrade*
}

Rodrigo da Silva Brandalise ${ }^{* *}$

\begin{abstract}
REFERÊNCIA
ANDRADE, Mauro Fonseca; BRANDALISE, Rodrigo da Silva. Observações preliminares sobre o acordo de não persecução penal: da inconstitucionalidade à inconsistência argumentativa. Revista da Faculdade de Direito da UFRGS, Porto Alegre, n. 37, p. 239-262, dez. 2017.
\end{abstract}

\section{RESUMO}

Recentemente, o Conselho Nacional do Ministério Público publicou a Resolução no 181 , de 07 de agosto de 2017, onde apresentou uma nova regulamentação para a investigação criminal presidida pelo acusador público brasileiro. Dentre as novéis disposições lá presentes, o que vem chamando muito a atenção dos operadores do direito é o denominado acordo de não-persecução penal, que se constitui em um acordo de não oferecimento da acusação pelo Ministério Público, dependente do cumprimento das condições firmadas pela pessoa investigada e seu defensor. Em razão disso, o objetivo do presente estudo é analisar a viabilidade dos argumentos apresentados pelo Conselho Nacional do Ministério Público para inserir esse instituto em nosso país. Em um primeiro momento, será analisado o parâmetro internacional utilizado, de modo a observar se é correta a equiparação entre a realidade alemã e a realidade brasileira. Ao depois, será averiguada a correção do argumento sistêmico invocado. Por fim, será averiguada a conformidade constitucional do acordo presente naquela resolução. A título de conclusão, apontar-se-á a inconstitucionalidade do acordo de não-persecução penal, e a inconsistência dos argumentos apresentados pelo Conselho Nacional do Ministério Público.

\section{PALAVRAS-CHAVE}

Acordo. Acusação. Princípio acusatório. Sistema acusatório. Interesse processual.

\begin{abstract}
On August 7 th 2017, the Brazilian National Council of Public Prosecutors published its Resolution 181, which introduced a new regulation to the criminal investigations led by Prosecutors in Brazil. Among all dispositions presented in this new act, there is a special novelty: the possibility of an agreement of no criminal prosecution between prosecutors and defendants assisted by their lawyers. If it is celebrated, the defendants will need to accomplish the conditions imposed and, as a final benefit, they will not be charged and sentenced for the crime committed. Because of it, this study aims to analyze the feasibility of the arguments presented by the Brazilian National Council of Public Prosecutors to establish this legal institute in Brazil. In a first step, it will be analyzed the international standard used, in order to see if it is correct the equivalence between German and Brazilian realities. After that, it will analyze the correctness of the claimed systemic argument. Finally, it will be checked whether the agreement presented in that Resolution is constitutionally suitable. In conclusion, it will be pointed the unconstitutionality of the Brazilian agreement of no criminal prosecution and the inconsistency of the arguments presented by the Brazilian National Council of Public Prosecutors.
\end{abstract}

\section{KEYWORDS}

Agreement. Prosecution. Accusatorial principle. Accusatorial system. Interest in bringing proceedings.

\footnotetext{
* Doutor em Direito Processual Penal pela Universidade de Barcelona (Espanha). Professor Adjunto da Universidade Federal do Rio Grande do Sul (UFRGS) e professor titular da Faculdade de Direito da Fundação Escola Superior do Ministério Público do Estado do Rio Grande do Sul.

** Mestre em Ciências Jurídico Criminais pela Faculdade de Direito da Universidade de Lisboa (Portugal). Pesquisador convidado do Max-Planck-Intitut für ausländisches und internationales Strafrecht em Freiburg im Breisgau (Alemanha). Promotor de Justiça no Estado do Rio Grande do Sul.
} 


\section{SUMÁRIO}

Introdução. 1. O Acordo de Não-Persecução Penal e sua Inserção no Direito Brasileiro. 2. O Argumento de Direito Comparado. 2.1. A invocação da experiência alemã. 2.2. O olvido da experiência portuguesa. 3. A Vinculação do Consenso Penal ao Sistema Acusatório. 4. A (In)Constitucionalidade do Acordo de Não-Persecução. 4.1. Sua difícil justificação constitucional frente à competência legislativa da União. 4.2. O interesse de agir como justificativa para o não ajuizamento da ação penal pública. 4.3. Um intento indevido de restrição à ação penal privada subsidiária da pública. Conclusão. Referências.

\section{INTRODUÇÃO}

O Conselho Nacional do Ministério Público, em setembro de 2017, publicou a Resolução $n^{\circ} 181$, destinada a regulamentar a investigação criminal presidida pelo acusador público brasileiro. Ela atendeu ao alerta dado pelo Supremo Tribunal Federal, no sentido de que esse modelo de investigação deveria se pautar pela observância dos direitos já reconhecidos legalmente às pessoas investigadas, seus defensores e às eventuais vítimas dos delitos apurados.

Em meio às suas disposições regulatórias, aquela resolução também se ocupou da criação de um instituto que nada tem a ver com a investigação criminal, mas sim, com uma lógica que diz respeito ao ajuizamento, ou não, da ação penal pública. Referimo-nos ao acordo de não-persecução penal, possível de ser firmado pelo Ministério Público e pela pessoa investigada - devidamente acompanhada de seu defensor -, onde constará o compromisso de não ser oferecida a acusação atinente ao fato investigado, caso o sujeito passivo da investigação cumpra com as condições ali pactuadas.

O debate relativo a esse acordo vem se dando de forma contundente, seja em sua defesa, seja em seu completo rechaço. No âmbito do Ministério Público nacional, algumas Procuradorias-Gerais de Justiça se manifestaram negativamente à pronta acolhida desse instituto, o que motivou uma forte tomada de posição por parte do Conselho Nacional do Ministério Público. Por outro lado, recentemente, duas Ações Diretas de Inconstitucionalidade foram ajuizadas, questionando não só aquele acordo, mas a própria resolução como um todo.

O objetivo do presente estudo, portanto, é fazer um claro recorte na discussão existente em torno desse tema, centrando nossa análise no meio utilizado pelo Conselho Nacional do Ministério Público para a criação do acordo de não-persecução penal (um ato de natureza administrativa), bem como, na validade e conformidade constitucional dos argumentos apresentados para a justificação teórica desse novel instituto.

\section{O ACORDO DE NÃO PERSECUÇÃO PENAL E SUA INSERÇÃO NO DIREITO BRASILEIRO}

No Brasil, a discussão sobre a legitimidade investigatória criminal do Ministério Público teve início nos anos 70 do século passado ${ }^{1}$, mas tomou corpo no começo do presente século, com a publicação dos primeiros

\footnotetext{
${ }^{1}$ BRASIL. Supremo Tribunal Federal. Processo Penal. Recurso em Habeas Corpus. Constrangimento ilegal. Recurso em Habeas Corpus $\mathrm{n}^{\circ}$ 48.728, do Tribunal de Justiça do Estado de São Paulo, Brasília, 26 de maio de 1971. Disponível em: http://redir.stf.jus.br/paginadorpub/paginador.jsp?docTP= AC\&docID=93199. Acesso em: 10 out. 2017.
} 
estudos monográficos voltados àquele tema ${ }^{2}$. A partir de então, esse assunto rompeu a barreira do trato meramente doutrinário, percorrendo todos os caminhos do sistema judiciário nacional até sua chegada ao Supremo Tribunal Federal.

O encerramento da controvérsia se deu com o julgamento do Recurso Extraordinário $\mathrm{n}^{\circ}$ 593.727, oportunidade em que aquela Corte, em repercussão geral, reconheceu a constitucionalidade da investigação criminal presidida pelo Ministério Público. No entanto, nosso Tribunal Constitucional deu um passo além, demonstrando sua preocupação com as garantias básicas que aquela investigação deveria observar, pois a regulamentação em vigor - a Resolução no 13/2006 - não era suficiente para assegurar os interesses da pessoa investigada, dos defensores (públicos ou constituídos) e de eventuais vítimas das infrações penais apuradas ${ }^{3}$. Essa preocupação serviu de incentivo para que a doutrina passasse a defender a existência de uma nova regulamentação para a investigação criminal do Ministério Público, embora entendesse que ela deveria ocorrer por lei, em lugar de seguir sendo por uma norma de caráter administrativo ${ }^{4}$.

Foram necessários alguns anos para que o Conselho Nacional do Ministério Público desse ouvidos ao alerta realizado pelo Supremo Tribunal Federal, o que ocorreu somente no ano de 2017, quando determinou o início do processo

\footnotetext{
${ }^{2}$ ANDRADE, Mauro Fonseca. Ministério Público e sua Investigação Criminal. Porto Alegre: Fundação Escola Superior do Ministério Público do Rio Grande do Sul, 2001. SANTIN, Valter Foleto. O Ministério Público na investigação criminal. Bauru: Edipro, 2001.

${ }^{3}$ BRASIL. Supremo Tribunal Federal. Processo Penal. Recurso Extraordinário. Recurso Extraordinário $\mathrm{n}^{\mathbf{0}}$ 593.727, do Tribunal de Justiça do Estado de Minas Gerais, Brasília, 14 de maio de 2015. Disponível em: http://redir.stf.jus.br/paginadorpub/paginador.jsp?docTP=T P\&docID=9336233. Acessado em: 10 out. 2017.

4 VIEIRA, Guilherme Siqueira. Poder Investigatório do Ministério Público: Apontamentos sobre a Necessidade de regulamentação. Revista Magister de Direito Penal $e$ Processual Penal, São Paulo, n. 71, p. 14-32, abr./maio 2016.
}

de adequação constitucional daquela regulamentação administrativa. A condução dos trabalhos ficou a cargo da Corregedoria Nacional do Ministério Público, que instaurou, em 18 de janeiro desse ano, o Procedimento de Estudos e Pesquisas $\mathrm{n}^{\mathrm{o}}$ 01, nomeando um grupo de membros do Ministério Público para a realização daquela tarefa ${ }^{5}$, cujo pronunciamento final foi apresentado em 22 de julho do mesmo ano ${ }^{6}$.

Como era de se esperar, houve uma minuciosa regulamentação do procedimento investigatório criminal - nome dado pelo Conselho Nacional do Ministério Público, ainda em 2006, à investigação presidida pelo acusador público nacional -, com a adequada preservação dos direitos e garantias de todos os sujeitos com atuação obrigatória ou facultativa naquele modelo de investigação criminal. Entretanto, a comissão de estudos apresentou proposta de inserção de um instituto que não guardava qualquer relação com a investigação criminal, estando ele ligado ao momento posterior à finalização da apuração criminal e à possibilidade de o Ministério Público não oferecer a ação penal pública mediante a realização de um acordo com a pessoa investigada. A esse instituto deu-se o nome de acordo de não-persecução penal.

Os argumentos apresentados para justificar aquele concerto de vontades disseram respeito à celeridade na resolução de crimes sem violência ou grave ameaça, à concentração da atuação do Poder Judiciário e do Ministério Público nos casos mais graves, à obtenção de uma maior economia dos recursos públicos e à

\footnotetext{
5 BRASIL. Conselho Nacional do Ministério Público. Procedimento de Estudos e Pesquisas 01. Despacho inaugural. Disponível em: http://www.cnmp.mp.br/portal/images/Despacho_inaugura 1_-_PEP_01-2017.pdf. Acesso em: 10 out. 2017.

${ }^{6}$ BRASIL. Conselho Nacional do Ministério Público. Procedimento de Estudos e Pesquisas 01. Pronunciamento Final em Procedimento de Estudos. Disponível em: http://www.cnmp.mp.br/portal/images/Pronunciamento_fi nal.pdf. Acesso em: 10 out. 2017.
} 
redução dos efeitos que uma sentença penal provocaria sobre as pessoas condenadas criminalmente.

A solução aos problemas e aspirações apresentados foi encontrada no direito comparado, mais especificamente, no direito alemão, por haver instituído um procedimento voltado à obtenção de consenso entre as partes, apesar de não existir, à época, qualquer previsão legal que validasse tal ajuste de vontades. Com o passar do tempo, no entanto, tal acordo teve sua constitucionalidade reconhecida pelo Poder Judiciário, com sua regulamentação legal efetivada pelo Poder Legislativo ${ }^{7}$.

Além do exemplo alemão, aquela comissão de estudos buscou se respaldar em termos constitucionais, invocando, para tanto, o princípio da eficiência e o fato de o Supremo Tribunal Federal haver reconhecido que a Constituição Federal haveria adotado, de forma inequívoca, o sistema acusatório. Ao final, afirmou-se que o cumprimento das condições pactuadas entre o Ministério Público e a pessoa investigada autorizaria a promoção pelo arquivamento do procedimento investigatório criminal, em razão da ausência de uma das condições autorizadoras do ajuizamento da ação penal pública. Ou seja, a execução integral dos termos do acordo levaria ao esvaziamento do interesse de agir por parte do Ministério Público, inviabilizando, com isso, eventual ajuizamento daquela ação penal, sob pena de sua rejeição ${ }^{8}$.

$\mathrm{O}$ resultado final desse estudo e da proposição do acordo de não-persecução penal foram acolhidos pelo Conselho Nacional do Ministério Público, que, após a abertura de um breve período para debate entre os demais membros do Ministério Público nacional,

\footnotetext{
7 BRASIL. Conselho Nacional do Ministério Público. Procedimento de Estudos e Pesquisas 01. Pronunciamento Final em Procedimento de Estudos. Ob. cit., p. 30.

8 BRASIL. Conselho Nacional do Ministério Público. Procedimento de Estudos e Pesquisas 01. Pronunciamento Final em Procedimento de Estudos. Ob. cit., p. 30.
}

aprovou a Resolução $\mathrm{n}^{\circ} 181$, que se dedicou a dispor "sobre instauração e tramitação do procedimento investigatório criminal a cargo do Ministério Público", tendo ela sido publicada e entrado em vigor em 08 de setembro de $2017^{9}$.

Previsto no artigo 18 daquela resolução ${ }^{10}$, o acordo de não-persecução penal não foi bem recebido por todos os Ministérios Públicos do país. De modo oficial, os Ministérios Públicos do Rio de Janeiro e Minas Gerais recomendaram a seus membros que se abstivessem de firmar aquele acordo até posterior deliberação. Em sentido mais radical foi o Ministério Público do Distrito Federal e Territórios, que se posicionou pela não aplicação integral da Resolução no 181/2017, até que fosse decidida a Questão de Ordem n ${ }^{\circ}$ 06/2017, e que fosse regulamentado o procedimento investigatório criminal pelo seu Conselho Superior.

Esse dissenso foi resolvido com a apresentação, por parte de membros do Ministério Público do Ceará, de Reclamação para Preservação da Competência e da Autoridade das Decisões do Conselho, noticiando a postura adotada pelos Ministérios Públicos do Rio de Janeiro, Minas Gerais e Distrito Federal e Territórios, e requerendo o reconhecimento do perfeito e imediato cumprimento da Resolução nº 181/2017.

Embora deferida a liminar pleiteada pelos requerentes em 28 de setembro de $2017^{11}$,

9 BRASIL. Conselho Nacional do Ministério Público. Resolução 181. Disponível em: http://www.cnmp.mp.br/portal/images/ED.169_-

6.9.2017.pdf. Acesso em: 10 out. 2017.

${ }^{10}$ Art. 18. Nos delitos cometidos sem violência ou grave ameaça à pessoa, não sendo o caso de arquivamento, o Ministério Público poderá propor ao investigado acordo de não-persecução penal, desde que este confesse formal e detalhadamente a prática do delito e indique eventuais provas de seu cometimento, além de cumprir os seguintes requisitos, de forma cumulativa ou não: (...).

11 BRASIL. Conselho Nacional do Ministério Público. Reclamação para Preservação da Competência e da Autoridade das Decisões do Conselho. Decisão Liminar, Brasília, 02 de outubro de 2017. Disponível em: 
não houve um apaziguamento na discussão envolvendo aquele acordo. Ao contrário, a viabilidade do acordo de não-persecução penal foi questionada por duas Ações Diretas de Inconstitucionalidade (ADI $\mathrm{n}^{\circ}$ 5790, de autoria da Associação Magistrados Brasileiros; e ADI ${ }^{\circ}$ 5.793, de autoria da Ordem dos Advogados do Brasil), sustentando, dentre outros argumentos, o desrespeito à competência exclusiva da União para legislar em matéria processual ${ }^{12}$.

Ao que se vê, seja pelo meio em que foi inserido em nosso direito (uma norma de natureza administrativa), seja pela invocação de temas de ordem constitucional, seja, enfim, por buscar respaldo no direito comparado, o acordo de não-persecução penal é um instituto altamente polêmico, que merece uma atenção maior por parte da doutrina, em razão dos valores altamente significativos envolvidos nesse debate: a segurança pública e o status libertatis do sujeito passivo da persecução penal.

\section{O ARGUMENTO DE DIREITO COMPARADO}

A iniciativa de implementação de acordos penais sem expressa previsão legal não é uma inovação brasileira. Pelo menos, dois países podem ser citados como paradigmas neste ponto - Alemanha e Portugal -, sendo que somente o caso alemão foi invocado pelo Conselho

\footnotetext{
https://diarioeletronico.cnmp.mp.br/apex/EDIARIO.view_ caderno?p_id=2964. Acesso em: 10 out. 2017.

12 BRASIL. Supremo Tribunal Federal. Processo Penal. Ação Direta de Inconstitucionalidade no 5790, Brasília, 06 de outubro de 2017. Disponível em: http://www.stf.jus.br/portal/processo/verProcessoAndamen to.asp. Acesso em 10 out. 2017. BRASIL. Supremo Tribunal Federal. Processo Penal. Ação Direta de Inconstitucionalidade $\mathrm{n}^{\circ}$ 57930, Brasília, 13 de outubro de $2017 . \quad$ Disponível em: http://www.stf.jus.br/portal/processo/verProcessoAndamen to.asp?incidente=5288159. Acesso em: 13 out. 2017.
}

Nacional do Ministério Público como precedente de direito comparado ${ }^{13}$.

Sendo assim, faz-se necessário falar sobre as iniciativas em tais países, e as consequências que lhes seguiram, nos limites do presente trabalho. Como será visto, o paradigma alemão não coincide com aquilo que o Conselho Nacional do Ministério Público quis realizar, e o que aconteceu em Portugal é forte fonte de preocupação.

\subsection{A invocação da experiência alemã}

Na Alemanha, a origem do acordo na esfera criminal (Absprachen) é obscura, mas remonta à década de 1970 . Seu começo se deu com a aplicação em delitos menores, mas, por não possuir previsão legal, foi adotado sem a realização de registros. Com o tempo, porém, ele passou a ser aplicado em delitos mais gravosos, inclusive aos que envolviam violência. Já, em 1982, um jurista alemão utilizou-se de pseudônimo (Detlef Deal from Mauschelhausen), e divulgou a prática daquele acordo, até então velada, motivando, a partir de então, um crescimento e uma maior divulgação na sua aplicação ${ }^{14}$.

Os acordos estabeleciam que, com a confissão, haveria agilização do processo e limitação da pena a ser imposta. Conforme o conteúdo e detalhamento da confissão, não haveria a necessidade de maior ou de qualquer dilação probatória, pois a negociação poderia acontecer antes ou durante o julgamento, com o

13 BRASIL. Conselho Nacional do Ministério Público. Procedimento de Estudos e Pesquisas 01. Pronunciamento Final em Procedimento de Estudos. Ob. cit., p. 30.

${ }^{14}$ KOBOR, Susanne. Bargaining in the criminal justice systems of the United States and Germany: matter of justice and administrative efficiency within legal. Frankfurt am Main: Internationaler Verlag der Wissenschaften, 2008, p. 123-125. 
possível envolvimento da acusação, do juízo e da defesa $^{15}$.

A matéria chegou aos tribunais superiores, o que permitiu ao Bundesgerichtshof ${ }^{16}$, em decisão de 28 de agosto de 1997, estabelecer os primeiros parâmetros para a viabilidade da Absprachen. Após longo período na informalidade, em 2009, surgiu, enfim, sua regulamentação legislativa, que consta no $§ 257 \mathrm{c}^{17}$ do Código de Processo Penal alemão (Strafprozeßordnung ou StPO $)^{18}$.

Poder-se-ia dizer que tal modelo se amolda à nossa realidade. Porém, há de se entender que um dos pontos que levaram à sua conformação - primeiro, pela jurisprudência; depois, pela legislação - é a legitimidade: quem conduz os acordos é o juiz ( $\$ 257 \mathrm{c}, \mathrm{n}^{\circ} 1$ e $\mathrm{n}^{\mathrm{o}} 3$, parte final, do StPO) ${ }^{19 / 20}$.

\footnotetext{
${ }^{15}$ ALTENHAIN, Karsten. Absprachen in german criminal trials. In: THAMAN, Stephen C. (Org.). World plea bargaining: consensual procedures and the avoidance of the full criminal trial. Durham: Carolina Academic Press, 2010, p. 159-161.

${ }^{16}$ Em tradução livre, Tribunal Federal de Justiça.

${ }^{17}$ ALEMANHA. The German code of criminal procedure (StPO). Code of Criminal Procedure in the version published on 7 April 1987 (Federal Law Gazette [Bundesgesetzblatt] Part I p. 1074, 1319), as most recently amended by Artcile 3 of the Act of 23 April 2014 (Federal Law Gazette Part I p. 410). Disponível em: https://www.gesetze-im-internet.de/englisch_stpo/. Acesso em: 13 out. 2017.

${ }^{18}$ Tal situação foi tida como constitucional por julgamento realizado em 2013 pelo Tribunal Constitucional alemão (BVerfg) (ALEMANHA. BVerfG, 2 BvR 2628/10, 2 BvR 2883/10 und BvR 2155/11, vom 19.3.2013. Berlin: Bundesverfassungsgericht, 2013, documento não paginado. Disponível em: http://www.bverfg.de/entscheidungen/rs20130319_2bvr26 2810.html. Acesso em: 13 out. 2017).

${ }^{19}$ KOBOR, Susanne. Bargaining in the criminal justice systems of the United States and Germany: matter of justice and administrative efficiency within legal. Frankfurt am Main: Internationaler Verlag der Wissenschaften, 2008, p. 151.

${ }^{20}$ Quanto ao papel do Ministério Público, conclui-se que ele é responsável em reforçar as exigências constitucionais, e tal controle é feito a partir de sua possibilidade de apelar das decisões embasadas nos acordos que desrespeitaram a Carta Maior (WEIGEND, Thomas; TURNER, Jenia Iontcheva. The constitutionality of negotiated criminal judgments in Germany. German
}

Ainda, há outras diferenças relevantes em relação ao acordo de não-persecução penal criado pelo Conselho Nacional do Ministério Público $^{21}$. Nesse sentido, verifica-se que, no caso do acordo alemão: (a) seu resultado deveria acontecer durante audiência pública, devidamente registrada; (b) se não acontecido em audiência, seus fundamentos deveriam ser trazidos para registro na Corte (conforme $\S 274^{22}$ do StPO) ${ }^{23}$; (c) ele deveria conduzir a um julgamento condizente com a culpa do acusado na prática do delito, pelo que incabível a negociação do conteúdo da acusação; (d) a confissão deveria ser apenas mais um elemento de prova, bem como, não poderia o juízo antecipar a pena que será imposta (em respeito ao previsto no $\S 261^{24}$ do $\left.\mathrm{StPO}\right)^{25}$, o que leva o

Law Journal, Lexington, v. 15, n. 1, feb. 2014, p. 96. Disponível em http://www.germanlawjournal.com/pdfs/FullIssues/GLJ\%2 0Vol\%2015\%20No\%201\%20Full\%20Issue.pdf. Acesso em: 13 out. 2017).

${ }^{21}$ A partir do que expõem, dentre outros: ALTENHAIN, Karsten. Absprachen in german criminal trials. In: THAMAN, Stephen C. (Org.). World plea bargaining: consensual procedures and the avoidance of the full criminal trial. Durham: Carolina Academic Press, 2010, p. 164-166; e LANGER, Máximo. From legal transplants to legal translations: the globalization of plea bargaining and the americanization thesis in criminal procedure. In: THAMAN, Stephen C. (Org). World plea bargaining: consensual procedures and the avoidance of the full criminal trial. Durham: Carolina Academic Press, 2010, p. 50-59)

${ }^{22}$ ALEMANHA. The German code of criminal procedure (StPO). Code of Criminal Procedure in the version published on 7 April 1987 (Federal Law Gazette [Bundesgesetzblatt] Part I p. 1074, 1319), as most recently amended by Artcile 3 of the Act of 23 April 2014 (Federal Law Gazette Part I p. 410). Ob. cit.

${ }^{23}$ KOBOR, Susanne. Bargaining in the criminal justice systems of the United States and Germany: matter of justice and administrative efficiency within legal. Frankfurt am Main: Internationaler Verlag der Wissenschaften, 2008, p. 148-149.

${ }^{24}$ ALEMANHA. The German code of criminal procedure (StPO). Code of Criminal Procedure in the version published on 7 April 1987 (Federal Law Gazette [Bundesgesetzblatt] Part I p. 1074, 1319), as most recently amended by Artcile 3 of the Act of 23 April 2014 (Federal Law Gazette Part I p. 410). Ob. cit. 
juiz a dever estar convencido do cometimento do fato descrito na acusação.

Ao que se percebe, o paradigma trazido como justificador da informalidade não se aplica ao caso brasileiro, visto que, dentre outras diferenças, o acordo alemão, inicialmente criado sem previsão legal, previa sua realização em âmbito processual e presidido pelo juiz, algo que vai em sentido completamente oposto ao acordo de não persecução-penal criado pelo Conselho Nacional do Ministério Público.

\section{$2.2 \mathrm{O}$ olvido da experiência portuguesa}

Apesar de não indicado nos estudos realizados que embasaram o acordo ora estudado, o caso português é bem mais relevante - e, por que não dizer, preocupante -, especialmente quando se observa a expressa previsão constitucional de uma estrutura acusatória em seu processo penal ${ }^{26}$.

Em nossa pátria-mãe, é possível ${ }^{27}$ que a confissão integral e sem reservas (sem alegação de tese defensiva) seja vista como uma renúncia à produção da prova relativa aos fatos imputados e consequente consideração destes como provados, nas hipóteses de crimes puníveis com pena de prisão de até 5 anos (Código de Processo

\footnotetext{
${ }^{25}$ Assim, a simples confissão, por mais detalhada que seja, não é suficiente para fundamentar um juízo condenatório (WEIGEND, Thomas; TURNER, Jenia Iontcheva. The constitutionality of negotiated criminal judgments in Germany. Ob. cit., p. 85).

${ }^{26}$ Constituição da República de Portugal, artigo $32^{\circ}, n^{\circ} 5$ (PORTUGAL. Constituição da República Portuguesa. Lisboa: Procuradoria-Geral Distrital de Lisboa. Disponível em:

<http://www.pgdlisboa.pt/leis/lei_mostra_articulado.php?n $\mathrm{id}=4 \&$ tabela=leis $>$. Acesso em: 13 out. 2017).

${ }^{27}$ Diz-se ser possível, porque o Tribunal sempre tem a liberdade de determinar a produção de outras provas se não se convencer acerca do caráter livre da confissão, especialmente no que diz com suspeitas de inimputabilidade e de falta de veracidade do conteúdo confessado (Código de Processo Penal, art. $344^{\circ}, \mathrm{n}^{\mathrm{o}} 3$, alínea 'b'. - PORTUGAL. Decreto-Lei n ${ }^{\circ} 78 / 87$, de 17 de fevereiro de 1987. Ob. cit.).
}

Penal português, artigo $344^{\circ}, n^{\circ} 1,2$, alínea 'a', e 3, alínea 'c'28).

Com base no regramento da confissão, houve a intenção de inclusão, via administrativa, do acordo negociado de sentença no seu sistema jurídico por iniciativa do Ministério Público, a partir da Orientação $n^{\circ} 1 / 2012$, da ProcuradoriaGeral Distrital de Lisboa ${ }^{29}$. Tal se deu também na Procuradoria-Geral Distrital de Coimbra, a partir do Memorando de 19 de janeiro de $2012^{30}$. Como se vê, o caminho lá percorrido é muito similar ao trilhado pelo Conselho Nacional do Ministério Público brasileiro. Contudo, a exemplo do que está ocorrendo no Brasil, tal tema aportou ao Supremo Tribunal de Justiça português. E, aqui, surge a grande preocupação.

Em decisão, a citada Corte entendeu que a aceitação de acordos de sentença, dentro do contexto lusitano, fere o princípio da legalidade, dado que inexiste previsão legal expressa em tal sentido. Assim, em razão de o Código de Processo Penal português, em seu artigo $126, \mathrm{n}^{\mathrm{o}} 1$, alínea "e" ${ }^{31}$, prescrever que a promessa de vantagem legalmente inadmissível é

${ }^{28}$ PORTUGAL. Decreto-Lei ${ }^{\circ} 78 / 87$, de 17 de fevereiro de 1987. Ob. cit.

${ }^{29}$ PORTUGAL. Procuradoria-Geral Distrital de Lisboa. Orientação $n^{\mathbf{o}}$ 01/2012, de 13 de janeiro de 2012. Procuradora-Geral Distrital Francisca Van Dunem emite uma orientação aos magistrados do MP do Distrito em sentido favorável a realização de acordos sobre a sentença em processo penal. Lisboa: Conselho Distrital do Porto da Ordem dos Advogados, 2011. Disponível em: http://www.pgdlisboa.pt/docpgd/doc_mostra_doc.php?nid $=153 \&$ doc $=$ files $/$ doc_0153.html . Acesso em: 13 out. 2017.

30 Além da confissão, baseou-se em hipóteses de atenuações de pena, na suspensão provisória do processo (Código de Processo Penal portugués, artigo 281) e no procedimento sumaríssimo (Código de Processo Penal portugués, artigo $392^{\circ}$, n. 2) (PORTUGAL. ProcuradoriaGeral Distrital de Coimbra. Memorando de 19 de janeiro de 2012. Justiça negociada: acordos sobre a sentença em processo penal. Coimbra: Procuradoria-Geral Distrital, 2012. Disponível em: http://www.oa.pt/upl/\%7Bee0e9275cf60-4420-a2f4-840bd0c0bb2b\%7D.pdf. Acesso em: 13 out. 2017).

${ }^{31}$ PORTUGAL. Decreto-Lei ${ }^{\circ} 78 / 87$, de 17 de fevereiro de 1987. Ob. cit. 
um método proibido de prova, entendeu-se que a prova obtida mediante o acordo era proibida, ordenando, pois, sua reprodução, com observância do regramento jurídico existente ${ }^{32}$. Por conta disto, houve um recuo do Ministério Público português com a publicação da Directiva $n^{\circ}$ 02/2014, da Procuradoria-Geral da República, determinando a abstenção de promoção ou aceitação da celebração de acordos sobre sentenças penais ${ }^{33}$.

De notar que o caput do artigo 18 da Resolução $n^{\circ}$ 181/2017 impõe, como condição para o acordo, que haja a entrega de provas pelo investigado para quem o investiga, tal como no caso português. A diferença está no fato de a confissão, no direito brasileiro, não ter o condão de afastar a instrução (Código de Processo Penal, artigos 197 e $\left.200^{34}\right)^{35}$, ao contrário do que ocorre em Portugal.

Este é o risco de quando se buscam parâmetros no direito estrangeiro sem considerar as consequências havidas na sua origem, podendo-se dizer que melhor sorte não espera $o$ caso brasileiro, assim que julgadas as Ações Diretas de Inconstitucionalidade já ajuizadas perante do Supremo Tribunal Federal.

\footnotetext{
${ }^{32}$ PORTUGAL. Supremo Tribunal de Justiça. Processo $\mathrm{n}^{\circ}$ 224/06.7GAVZL.C1.S1. Lisboa, 10 de abril de 2013. Disponível

http://www dosi pt/jstj nsf/954f0ce6ad9dd8b980256b5f00 3fa814/533bc8aa516702b980257b4e003281f0?OpenDocu ment. Acesso em: 13 out. 2017.

33 PORTUGAL. Procuradoria-Geral da República. Directiva $\mathrm{n}^{\circ}$ 02/2014, de 21 de fevereiro de 2014. Lisboa: PGR, 2014. Disponível em: http://www.ministeriopublico.pt/iframe/diretivas.

Acessado em: 13 out. 2017.

${ }^{34}$ BRASIL. Governo Federal. Código de Processo Penal. Disponível em: http://www.planalto.gov.br/ccivil_03/decretolei/Del3689Compilado.htm. Acesso em: 10 out. 2017.

${ }^{35}$ Há entendimento de que a legislação processual penal portuguesa possui disposições expressas que autorizam a iniciativa de introdução dos acordos (BRANDALISE, Rodrigo da Silva. Justiça penal negociada. Negociação de sentença criminal e princípios processuais penais relevantes. Curitiba: Juruá, 2016, p. 236, n.r. 1159), mas que, por opção de soberania, o Brasil não as repete.
}

\section{A VINCULAÇÃO DO CONSENSO PENAL AO SISTEMA ACUSATÓRIO}

No âmbito doutrinário, a discussão em torno da definição do sistema processual penal adotado em nosso país vem apresentando uma clara divisão de posições, havendo quem defensa que temos o sistema acusatório ${ }^{36}$, o sistema misto $^{37}$ e, até mesmo, o sistema inquisitivo ${ }^{38}$. Há um setor, inclusive, que defende a ausência de um sistema processual penal definido, razão pela qual sustenta sua inserção, de modo claro e definitivo, no texto constitucional ou no Código de Processo Penal ${ }^{39}$. Aparentemente, esta última posição foi adotada pelo legislador no projeto de novo Código de Processo Penal ${ }^{40}$, em razão de haver se dedicado a fazer menção expressa, no seu artigo $4^{\circ}$, à vinculação do futuro processo penal lá desenhado ao que chamou de estrutura acusatória ${ }^{41}$.

Alheio a essa discussão, o Supremo Tribunal Federal vem, de longa data, firmando posição sobre qual haveria sido o sistema processual penal adotado pela Constituição Federal. Para essa Corte, as disposições constitucionais haveriam apontado - ainda que implicitamente, mas de forma inequívoca - a opção do legislador pelo sistema acusatório, o que também lhe permitiu afirmar, em um julgado

36 OLIVEIRA, Eugênio Pacelli de. Curso de Processo Penal. 20. ed. São Paulo: Atlas, 2016, p. 10. LIMA, Marcellus Polastri. Curso de Processo Penal. 9. ed. Brasília: Gazeta Jurídica, 2016, p. 23.

37 NUCCI, Guilherme de Souza. Manual de Processo Penal e Execução Penal. 13. ed. Rio de Janeiro: forense, 2016, p. 74.

${ }^{38}$ LOPES JÚNIOR, Aury. Direito Processual Penal. 13. ed. São Paulo: Saraiva, 2016, p. 47.

39 ANDRADE, Mauro Fonseca. Sistemas Processuais Penais e seus Princípios Reitores. 2. ed. Curitiba: Juruá, 2013, p. 471-476.

${ }^{40}$ BRASIL. Câmara dos Deputados. Projeto de Lei $\mathrm{n}^{\circ}$ 8.045, de 2010. Disponível em: http://www.camara.gov.br/proposicoesWeb/fichadetramita cao?idProposicao=490267. Acesso em: 10 out. 2017.

${ }^{41}$ Art. $4^{\circ}$. O processo penal terá estrutura acusatória, nos limites definidos neste Código, vedada a iniciativa do juiz na fase de investigação e a substituição da atuação probatória do órgão de acusação. 
específico, que, em razão dessa opção, haveria a necessidade de "uma mudança profunda na condução das investigações criminais e no processamento das ações penais no Brasil" "42.

Em razão desse duplo posicionamento do Supremo Tribunal Federal - indicação de albergue constitucional para o sistema acusatório, e premência na revisão completa de nossa persecução penal -, o Conselho Nacional do Ministério Público entendeu possuir o respaldo necessário para justificar a inserção do acordo de não-persecução penal, ainda que fosse em uma resolução destinada a regulamentar sua investigação criminal. Entretanto, o significado dado ao sistema acusatório pelo Conselho Nacional do Ministério Público, ao que parece, é algo decorrente de sua visão particular.

No Brasil, é possível encontrar 04 linhas teóricas que se propõem a definir o sistema acusatório. Nesse sentido, há quem o defina: a) simplesmente identificando a separação entre quem acusa e quem julga ${ }^{43}$; b) a partir da existência de diversas garantias processuais, entre elas, a imparcialidade do juiz, contraditório, ampla defesa, oralidade e publicidade $^{44}$; c) em razão da inércia absoluta do juiz na fase probatória ${ }^{45}$; e d) a partir da imprescindibilidade de um acusador distinto do juiz, e do fato de o processo somente ter seu

\footnotetext{
${ }^{42}$ BRASIL. Supremo Tribunal Federal. Processual Penal. Ação Direta de Inconstitucionalidade. Ação Direta de Inconstitucionalidade $\mathrm{n}^{\mathrm{o}}$ 5104, Brasília, 21 de maio de 2014. Disponível em: http://redir.stf.jus.br/paginadorpub/paginador.jsp?docTP=T P\&docID=7088758. Acesso em: 10 out. 2017.

${ }^{43}$ GRINOVER, Ada Pellegrini. Liberdades Públicas e Processo Penal (as interceptações telefônicas). 2. ed. São Paulo: RT, 1982, p. 27, nota 63. COSTA, Paula Bajer Fernández Martins da. Ação Penal Condenatória. São Paulo: Saraiva, 1995, p. 62.

${ }^{44}$ DEZEM, Guilherme Madeira. Curso de Processo Penal. 3. ed. São Paulo: RT, 2017, p. 99.

45 COUTINHO, Jacinto Nelson de Miranda. Sistema Acusatório. Cada parte no lugar constitucionalmente demarcado. Revista de Informação Legislativa, Brasília, v. 183, p. 103-116, jul./set. 2009.
}

início com o ajuizamento da ação ${ }^{46}$. Como se vê, em absolutamente nenhuma dessas correntes doutrinárias há a referência ao consenso como elemento obrigatório para a configuração do sistema acusatório.

Afora o meio doutrinário, também depõe contra a tentativa de vinculação sistêmica com o acordo de não-persecução, o fato de o próprio Supremo Tribunal Federal identificar a opção constitucional pelo sistema acusatório, mesmo sem a existência desse acordo. Em razão disso, é possível dizer que nossa Corte Constitucional faz a devida separação entre o sistema acusatório e o consenso no processo penal, ainda que reconheça a possibilidade de consenso quando há previsão constitucional (como é o caso dos juizados especiais, mencionados no inciso I do seu artigo 98) e/ou legal (como é o caso da colaboração premiada).

Seja como for, mostra-se mais que inexata a vinculação obrigatória que o Conselho Nacional do Ministério Público faz entre o sistema acusatório e o acordo de não-persecução penal, o que nos leva a concluir que o consenso não é uma decorrência lógica desse sistema, podendo ele muito bem existir sem o instituto criado pela Resolução no 181/2017.

\section{A (IN)CONSTITUCIONALIDADE DO ACORDO DE NÃO-PERSECUÇÃO}

A análise da conformidade constitucional de todo novel instituto é procedimento obrigatório para se atestar a preservação dos interesses persecutórios do Estado e defensivos do sujeito passivo da persecução penal. Quando tal instituto vem acompanhado das razões de sua criação, essa análise se vê naturalmente ampliada, como é o caso do acordo de não-persecução penal.

\footnotetext{
46 ANDRADE, Mauro Fonseca. Sistemas Processuais Penais e seus Princípios Reitores. 2. ed. Curitiba: Juruá,
} 2013, p. 471-476. 
A esse filtro constitucional é que nos dedicaremos agora.

4.1 Sua difícil justificação constitucional frente à competência legislativa da União

Em continuidade ao exame do acordo de não-persecução penal, faz-se imprescindível um exame essencial junto à compreensão do Supremo Tribunal Federal sobre dois pontos nevrálgicos e umbilicalmente ligados: a consideração de que o Ministério Público pode investigar, e o alcance de normatização conferido aos Conselhos Nacionais.

$\mathrm{O}$ primeiro ponto (poder de investigação do Ministério Público) foi definido, em repercussão geral, quando do julgamento do Recurso Extraordinário $\mathrm{n}^{\mathrm{o}}$ 593.727/MG. Entretanto, há de ser verificado o que aquela Corte assentou sobre o tema.

Em seu voto, o Ministro Luiz Fux externou que o poder investigatório do Ministério Público “[...] proporciona, verbi gratia, a melhor forma de zelar pela plena observância do princípio da obrigatoriedade [...]" 47 . Ou seja, ao entender constitucional o poder investigatório do Ministério Público, o Supremo Tribunal Federal o fez reafirmando que estamos na vigência da obrigatoriedade da ação penal. Aliás, no mesmo voto, o Ministro expressa que a investigação ministerial deve ser feita cercada dos limites da legalidade e do conteúdo constitucional. No entanto, outra nota é constante durante o julgamento: a admissão de que a investigação ministerial tem limites essenciais, sendo que um deles, que guarda relação com o presente trabalho, é que a investigação ministerial está regulada, por analogia, pelas normas que regem o inquérito policial.

${ }^{47}$ BRASIL. Supremo Tribunal Federal. Processo Penal. Recurso Extraordinário. Recurso Extraordinário $\mathrm{n}^{\circ}$ 593.727, do Tribunal de Justiça do Estado de Minas Gerais, Brasília, 14 de maio de 2015. Ob. cit.
Sucintamente, extrai-se que o Supremo Tribunal Federal trabalhou, ao reconhecer o poder investigatório do Ministério Público, que se está diante do princípio da obrigatoriedade da ação penal, que esta é regulada por lei e que, na falta de regulamentação própria, devem ser usados os parâmetros do inquérito policial como analogia.

Apesar de não ser fruto de um dispositivo constitucional ou legalmente expresso, a obrigatoriedade da ação penal decorre da interpretação de diversos dispositivos, tanto de cunho constitucional como infraconstitucional $^{48}$, considerando o que diz o já citado artigo 129, inciso I, da Constituição Federal.

Os parâmetros do inquérito policial estão estabelecidos em lei, especialmente no Código de Processo Penal, onde também está, precipuamente, o tratamento da ação e do processo penal (artigo $1^{\circ}$ ). A seu turno, a Constituição Federal, em seu artigo 129, inciso I, estabelece que a titularidade privativa para o exercício da ação penal conferida ao Ministério Público deve ser feita nos termos da lei.

Assim, decorre a pergunta essencial: tem o Conselho Nacional do Ministério Público a possibilidade de editar leis processuais penais? $\mathrm{Ou}$, dito de outra forma: tem ele poder legislativo nesta área?

A resposta, ao que se pode depreender da Constituição Federal e de decisões do Supremo Tribunal Federal, é negativa, o que inquina a Resolução $\mathrm{n}^{\circ} 181 / 2017$, no que diz respeito ao acordo de não-persecução penal, de

${ }^{48}$ Consoante os termos vigentes do artigo 42 e do artigo 576, ambos do Código de Processo Penal brasileiro, não pode o Ministério Público desistir da ação penal, nem do recurso interposto. Ainda, o artigo 28 do Código de Processo Penal, que estabelece a possibilidade de o juiz, ao não concordar com a promoção de arquivamento, encaminhá-la para exame do Procurador-Geral do respectivo Ministério Público que pode concordar com o arquivamento, promover ele próprio a ação penal ou designar outro agente ministerial para que ela seja proposta. 
vício de origem que afeta sua constitucionalidade. Justifica-se.

Nossa Constituição Federal, em seu artigo 22, inciso $\mathrm{I}$, diz que compete, privativamente, à União legislar sobre direito processual, dentre outras matérias ali também descritas. No artigo 24, inciso XI, refere que compete à União, aos Estados e ao Distrito Federal legislar, concorrentemente, sobre procedimentos em matéria processual. Basta ler o artigo 130-A da mesma Carta para verificar que o Conselho Nacional do Ministério Público não compreende absolutamente nenhum dos conceitos antes mencionados.

Não ao acaso, na Ação Direta de Inconstitucionalidade $\mathrm{n}^{\mathbf{o}} 2970^{49}$, o Supremo Tribunal Federal deixou claro que, com o advento da Constituição Federal de 1988, o poder de expedição de normas processuais, em regimentos internos dos Tribunais, estava limitado à reserva da lei federal, nos termos do artigo 22, inciso I, da Lei Maior. E mais: deixa bem presente que normas de direito processual são aquelas que dizem respeito ao contraditório, devido processo legal, poderes, direitos e ônus da relação processual, assim como, aqueles que dizem com a regulamentação de atos destinados a efetivar a causa finalis da jurisdição.

Ao Conselho Nacional do Ministério Público não the foi dada, portanto, qualquer legitimidade para legislar na matéria processual e/ou procedimental penal, sendo evidente o caráter processual da Resolução n ${ }^{\circ}$ 181/2017, pois ela diz com o (não) exercício da ação penal e o seu respectivo processo.

Poder-se-ia objetar o afirmado anteriormente com a consideração de que o Supremo Tribunal Federal já reconheceu a capacidade normativa do Conselho Nacional de

\footnotetext{
${ }^{49}$ BRASIL. Supremo Tribunal Federal. Processo Penal. Ação Direta de Inconstitucionalidade. Ação Direta de Inconstitucionalidade no 2970 , Brasilia, 20 de abril de 2006. Disponível em: http://redir.stf.jus.br/paginadorpub/paginador.jsp?docTP=AC\&docID=
} 266970. Acesso em: 10 out. 2017.
Justiça, o que não se desconhece. Entretanto, referido reconhecimento encontra limites importantes e que, por simetria, também são aplicáveis ao Conselho Nacional do Ministério Público. Vamos a eles.

O primeiro julgado que merece atenção é o que consta na Medida Cautelar em Ação Declaratória de Constitucionalidade $\mathrm{n}^{\circ} 12^{50}$. Nela, o Supremo Tribunal Federal enfrentou a temática que envolvia a Resolução no 07/2005, do Conselho Nacional de Justiça, em seu artigo $3^{\circ}$. O objeto da resolução indicada era o de realizar a disciplina do exercício de cargos, empregos e funções por parentes, cônjuges e companheiros de magistrados e de servidores investidos em cargos de direção e assessoramento, no âmbito do Poder Judiciário.

Nesse julgamento, foi reconhecido que a resolução era dotada de abstratividade, generalidade e impessoalidade, o que a tornaria um ato normativo primário ${ }^{51}$. Contudo, o Conselho Nacional de Justiça somente tem poder de editar referidos atos, se limitados aos termos do artigo 103-B, § $4^{\circ}$ e incisos, da Constituição Federal. Em suma, os limites dizem respeito à atuação administrativa e financeira do Poder Judiciário, pois é ele um órgão de planejamento estratégico do Poder Judiciário, de molde que é uma genuína instância do Poder Judiciário ${ }^{52}$. Por consequência, aquela resolução estava

${ }^{50}$ BRASIL. Supremo Tribunal Federal. Direito Administrativo. Direito Civil. Medida Cautelar em Ação Declaratória de Constitucionalidade $\mathrm{n}^{\circ}$ 12, Brasilia, 16 de fevereiro de 2006. Disponível em: http://redir.stf.jus.br/paginadorpub/paginador.jsp?docTP=AC\&docID= 372910. Acesso em: 10 out. 2017.

${ }^{51}$ Por todos: CABRAL, Rodrigo Leite Ferreira. $O$ acordo de não-persecução penal criado pela nova Resolução do CNMP. CONAMP: Brasília, 2017, documento não paginado. Disponível em: https://www.conamp.org.br/pt/biblioteca/artigos/item/1783 -o-acordo-de-nao-persecucao-penal-criado-pela-novaresolucao-do-

cnmp.html?utm_campaign=artigo_o_acordo_de_naopersecucao_penal_criado_pela_nova_resolucao_do_cnmp \&utm_medium=email\&utm_source=RD+Station. Acesso em: 13 out. 2017.

52 Expressões e explicações constantes no voto do relator, Ministro Carlos Ayres Britto. 
vinculada a atender os princípios constitucionais de centrada regência de toda a atividade administrativa do Estado, o que levou a considerar que o Conselho Nacional de Justiça fez adequado uso da competência que the outorgou a Constituição Federal ${ }^{53}$.

Importante outra consideração também externada durante o julgamento: a diferenciação entre a reserva de lei e a reserva da norma. A primeira reserva surge quando se depende de definição legal, como o que ocorre a partir do conteúdo do artigo $5^{\circ}$, inciso II, da Constituição Federal - somente a lei pode tratar determinadas matérias (casos em que descabem regulamentos e regimentos). A segunda reserva traz as definições que são consequências da lei já existente. E, no ponto, ficou devidamente claro: o Conselho Nacional de Justiça não dispõe de função legislativa, já que sua função é normativa regulamentar ${ }^{54}$. Ou, como disse o, então, Ministro Joaquim Barbosa, "somente a lei [...] teria primazia de criar direitos e obrigações"

Ainda que se entenda ser possível a alegação de poderes implícitos ao Conselho Nacional de Justiça, por necessidade de respeito ao artigo 37 da Constituição Federal, tal se deu para reger a atuação administrativa do Poder Judiciário, pelo que seus atos normativos devem ser feitos nesse específico sentido.

Concretamente, no caso ali analisado, não se vislumbrava a necessidade de lei formal para proibição do nepotismo, pois isso decorre dos princípios constitucionais da moralidade e da impessoalidade. Entretanto, esse não é o único julgamento relevante sobre o Conselho Nacional de Justiça.

No Mandado de Segurança $n^{\circ} 27.621$, também se adotou a compreensão de que $o$

\footnotetext{
${ }^{53}$ Expressões e explicações constantes no voto do relator, Ministro Carlos Ayres Britto.

${ }^{54}$ Expressões e explicações constantes no voto Ministro Eros Grau.

${ }^{55}$ BRASIL. Supremo Tribunal Federal. Direito Administrativo. Direito Civil. Medida Cautelar em Ação Declaratória de Constitucionalidade $\mathrm{n}^{\circ}$
} 12. Brasilia, 16 de fevereiro de 2006 . Ob. cit.
Conselho Nacional de Justiça é órgão com atribuições exclusivamente administrativas $e$ correicionais, ainda que, estruturalmente, integre o Poder Judiciário. A propósito, disse o Ministro Ricardo Lewandowski que, apesar de integrante do Poder Judiciário, aquele Conselho não possui funções jurisdicionais, mas administrativas e correicionais ${ }^{56 / 57}$. Disso se extrai que, se o Conselho Nacional de Justiça não pode julgar, apesar de compor o Poder Judiciário, com muito menos razão poderá legislar além dos poderes constitucionalmente instituídos, pois não compõe o Poder Legislativo.

Também é relevante a Medida Cautelar em Ação de Descumprimento de Preceito Fundamental $\mathrm{n}^{\text {o }} 347^{58}$, na qual, ao ser reconhecido o chamado estado de coisas inconstitucional no sistema penitenciário brasileiro, também se tratou da imposição de realização da, assim, chamada audiência de custódia ${ }^{59}$.

Sabido é que a audiência de custódia está regulamentada pela Resolução no 213/2015, do Conselho Nacional de Justiça. Não obstante, isso não serve como parâmetro de analogia para legitimar qualquer inovação de cunho processual penal por parte do Conselho Nacional do Ministério Público.

Primeiro, porque a audiência de custódia não dita o destino da ação penal. Sua

56 BRASIL. Supremo Tribunal Federal. Direito Constitucional. Mandado de Segurança $n^{\circ}$ 27621, do Conselho Nacional de Justiça, Brasília, 07 de dezembro de 2011. Disponível em: http://redir.stf.jus.br/paginadorpub/paginador.jsp?docTP=TP\&docID=1 983588. Acesso em: 10 out. 2017.

${ }^{57}$ De ser notado que o remédio constitucional se voltava contra determinação constante no Pedido de Providências

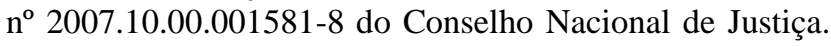
Por ela, todos os juízes brasileiros com função executiva deveriam estar cadastrados junto ao sistema BACENJUD.

58 BRASIL. Supremo Tribunal Federal. Direito Constitucional. Execução Penal. Arguição de Descumprimento de Preceito Fundamental no 347, Brasilia, 09 de setembro de 2015. Disponível em: http://redir.stf.jus.br/paginadorpub/paginador.jsp?docTP=TP\&docID=1 0300665. Acesso em: 10 out. 2017.

59 Como expressado no acórdão: “[...] a imposição da realização de audiências de custódia há de ser estendida a todo o Poder Judiciário do país [...]". 
realização ou não, quando muito, interferirá em um momento da análise da prisão provisória havida, mas, em hipótese alguma, a persecução penal será extinta, modificada ou desconstituída por causa de sua ausência. E, principalmente, porque sua não ocorrência sequer interfere na validade da prisão que a originara ${ }^{60}$.

Segundo, porque, naquele julgamento, o Supremo Tribunal Federal reconheceu que a medida decorre do artigo 9, $\mathrm{n}^{\circ} 3$, do Pacto dos Direitos Civis e Políticos, e do artigo $7, \mathrm{n}^{\circ} 5$, da Convenção Interamericana de Direitos Humanos, que, uma vez já internalizados no Brasil, possuem hierarquia legal. Noutros termos, não foi a Resolução do Conselho Nacional de Justiça que inovou; ela apenas regulou algo que a lei determina.

Evidencia-se, portanto, que não existe possibilidade do Conselho Nacional de Justiça legislar além dos limites estabelecidos na Constituição Federal, o que, mutatis mutandis, deve ser aplicado ao Conselho Nacional do Ministério Público ${ }^{61 / 62}$. Logo, ele não pode

${ }^{60}$ Diz o Superior Tribunal de Justiça: "Não se vislumbra ilegalidade passível de concessão da ordem de ofício quando não realizada a audiência de custódia, uma vez que a jurisprudência desta Corte é firme no sentido de que eventual nulidade do flagrante fica superada com a superveniência do decreto de prisão preventiva (precedentes)" (BRASIL. Superior Tribunal de Justiça. Processo Penal. Recurso em Habeas Corpus $\mathrm{n}^{\mathrm{o}}$ 85.101, Brasília, 15 de agosto de 2017. Disponível em: https://ww2.stj.jus.br/processo/revista/documento/mediado $/$ ?componente=ITA\&sequencial $=1623769 \&$ num_registro= $201701277234 \&$ data $=20170821 \&$ formato $=$ PDF. Acesso em: 10 out. 2017).

${ }^{61}$ Nossa Constituição Federal, em seu, artigo 130-A, § $2^{\circ}$, inciso I, autoriza que o Conselho Nacional do Ministério Público expeça atos regulamentares no âmbito de sua competência, para controle da atuação administrativa e financeira do Ministério Público e do cumprimento dos deveres funcionais de seus membros.

62 Conforme expressa a doutrina, o Supremo Tribunal Federal, na ADIN 3.367/DF, afirmou a natureza administrativa do Conselho Nacional de Justiça. Com base nessa decisão, a partir da simetria entre os dois Conselhos, afirma-se que essa também é a natureza do Conselho Nacional do Ministério Público, o que limita a atuação e a interpretação a ser feita por ele (ZIESEMER, Henrique da Rosa. Direito Institucional. Comentários ao Regimento expedir leis e, por consequência, inovar na maneira de regulamentação de nosso processo penal. Do contrário, além da clara infringência ao inciso I do artigo 22 da Constituição Federal, estará ele próprio desrespeitando a decisão do Supremo Tribunal Federal, que reconheceu o poder investigatório do Ministério Público, como citado acima, já que não há tal previsão relativa aos inquéritos policiais.

Para referendar isto, reporta-se à Medida Cautelar em Ação Direita de Inconstitucionalidade $n^{\circ}$ 5.104. Na essência, foi proposta contra os artigos $3^{\circ}$ a 13 da Resolução $n^{\circ}$ 23.396, de 17 de dezembro de 2013, do Tribunal Superior Eleitoral. No ponto onde foi deferida a cautelar postulada, versava a resolução que o inquérito policial eleitoral somente será instaurado mediante determinação da Justiça Eleitoral, salvo a hipótese de prisão em flagrante. Esse dispositivo foi tido como violado em consideração com as regras do sistema acusatório; porém, o Supremo Tribunal Federal reconheceu que, ainda que o legislador disponha de alguma margem de conformação do conteúdo concreto do princípio acusatório, essa mesma prerrogativa não é atribuída ao Tribunal Superior Eleitoral, no exercício de sua competência normativa atípica ${ }^{63}$.

Enfim, seja por que via for, jamais o Supremo Tribunal Federal chancelou os diversos intentos de se legislar em matéria processual mediante atos de natureza administrativa, como é o caso da Resolução no 181/2017, do Conselho Nacional do Ministério Público.

Interno do Conselho Nacional do Ministério Público. 2. ed. Rio de Janeiro: Lumen Juris, 2017, p. 7-9).

${ }^{63}$ BRASIL. Supremo Tribunal Federal. Direito Eleitoral. Processo Penal. Medida Cautelar em Ação Direta de Inconstitucionalidade $\mathrm{n}^{\circ}$ 5104, Brasilia, 21 de maio de 2014. Disponível em: http://redir.stf.jus.br/paginadorpub/paginador.jsp?docTP=TP\&docID=7 088758. Acessado em: 10 out. 2017. Nesse mesmo julgado, como bem pontuou o Ministro Ricardo Lewandowski, que “(...) as resoluções eleitorais só podem ser expedidas segundo a lei, secundum legem, ou para suprir alguma lacuna normativa, praeter legem, sem contudo inovar em matéria legislativa ou contrariar dispositivo legal, contra legem". 
4.2 $\mathrm{O}$ interesse de agir como justificativa para o não ajuizamento da ação penal pública

O estudo atinente às condições da ação no direito processual penal não apresenta resultados convergentes. Antes mesmo da vigência do novo Código de Processo Civil, havia autores defendendo a equivalência entre as condições da ação civil e as condições da ação penal $^{64}$, e quem defendesse seu apartamento por completo dos parâmetros traçados pela teria geral do processo, apresentando condições da ação próprias ao direito processual penal ${ }^{65} / 66$.

Essa breve referência se faz necessária porque o Conselho Nacional do Ministério Público seguiu o entendimento tradicional $-\mathrm{e}$, não por isso, menos correto -, optando pela equivalência das condições da ação penal com as condições da ação civil. Essa opção fica clara, em razão da justificativa dada para o requerimento de arquivamento nos casos de cumprimento do acordo de não-persecução por parte da pessoa investigada ${ }^{67}$, qual seja, uma

${ }^{64}$ GRINOVER, Ada Pellegrini. As Condições da Ação Penal. São Paulo: José Bushatsky, 1977.

${ }^{65}$ LOPES JÚNIOR, Aury. (Re)Pensando as condições da Ação Processual Penal. In: GAUER, Ruth Maria Chittó (Org.). Criminologia e Sistemas Jurídico-Penais Contemporâneos. Porto Alegre: EdiPUCRS, 2008. p. 277306.

66 Essa divergência segue existindo. Sobre ela, ver: SILVEIRA, Marco Aurélio Nunes da. As Condições da Ação no Direito Processual Penal. Sobre a Inadequação das Condições da Ação Processual Civil ao Juízo de Admissibilidade da Acusação. Florianópolis: Empório do Direito, 2016. BOSCHI, Marcus Vinicius. Ação, Pretensão e Processo Penal. Teoria da Acusação. Porto Alegre: Livraria do Advogado, 2015, p. 227-232.

${ }^{67}$ Art. 19. Se o membro do Ministério Público responsável pelo procedimento investigatório criminal se convencer da inexistência de fundamento para a propositura de ação penal pública ou constatar o cumprimento do acordo de não-persecução, nos termos do art. 17, promoverá o arquivamento dos autos ou das peças de informação, fazendo-o fundamentadamente. (BRASIL. Conselho Nacional do Ministério Público. Resolução 181. Disponível em: https://diarioeletronico.cnmp.mp.br/apex/EDIARIO.view_ caderno?p_id=2964. Acesso em: 10 out. 2017) alegada ausência de interesse de agir, ou, nas exatas palavras contidas no Pronunciamento Final do Procedimento de Estudos e Pesquisa $n^{o}$ 01 daquele Conselho, com o cumprimento do acordo, "já estaria suficientemente satisfeita a pretensão punitiva Estatal" $"$.

Ora, ao que se nota, ninguém menos que o Ministério Público - que, por mandamento constitucional, foi erigido à condição de defensor da ordem jurídica (art. 127, caput) ${ }^{69}$ - vê a si próprio como legitimado a impor pena em âmbito criminal, pois a "pretensão punitiva Estatal" somente pode ser satisfeita com a imposição de sanção legalmente prevista. A violação à Constituição Federal estaria presente, dessa forma, pela infringência ao brocardo latino nulla poena sine iudicio, presente no inciso LIV do seu artigo $5^{\circ} 70$, já que ele entende que os termos de seu acordo se constituem em verdadeira pena a ser cumprida pela pessoa investigada.

Esse grave erro deriva do próprio conceito de interesse de agir utilizado pelo Conselho Nacional do Ministério Público. Segundo a melhor doutrina, o interesse de agir se justifica pela necessidade do provimento judicial e pela adequação do provimento pedido à vontade da lei ${ }^{71}$. Assim, se a imposição de pena não cabe ao Ministério Público, mas ao Poder Judiciário, e se a pena a ser imposta por este último estiver dentro dos limites legalmente previstos, não há como negar a permanência do interesse de agir, mesmo com a realização e cumprimento do acordo de não-persecução penal por parte da pessoa investigada. Se, como

68 BRASIL. Conselho Nacional do Ministério Público. Procedimento de Estudos e Pesquisas 01. Pronunciamento Final em Procedimento de Estudos. Ob. cit., p. 31.

69 BRASIL. Governo Federal. Constituição Federal. Disponível em: http://www.planalto.gov.br/ccivil_03/constituicao/constitui cao.htm. Acesso em: 10 out. 2017.

${ }^{70}$ BRASIL. Governo Federal. Constituição Federal. Ob. cit.

${ }^{71}$ GRINOVER, Ada Pellegrini. As Condições da Ação Penal. São Paulo: José Bushatsky, 1977, p. 87-96. 
representante da sociedade, não cabe ao Ministério Público a "autoexecutoriedade do direito de punir" ${ }^{72}$, por óbvio que, em razão disso, latente estará o interesse de agir a justificar o ajuizamento da ação penal pública, que, no caso, caberá a ele próprio.

Se algum acordo devesse existir entre Ministério Público e o sujeito passivo da persecução penal, deveria ele se dar a partir do ajuizamento da acusação ou motivando o seu oferecimento (levando-se o acordo à apreciação judicial). É por isso que, na Alemanha (conforme visto acima), a negociação entre Ministério Público e sujeito passivo somente se dava após o oferecimento da acusação, pois o interesse de agir motivou a busca da punição daquele, ainda que de forma ajustada com o acusador público e o Poder Judiciário.

Por outro lado, ainda que o entendimento do Conselho Nacional do Ministério Público fosse considerado correto, a consequência prática dessa definição de interesse de agir é a criação de um problema ainda maior para o Ministério Público nacional, mas não dimensionado por aquele Conselho. Melhor explicando, se a ausência de interesse de agir decorreria do cumprimento do acordo de nãopersecução penal, por qual motivo esse acordo não poderia ser realizado em toda e qualquer infração penal, em lugar de somente ser possível naquelas em que não houver violência ou grave ameaça à pessoa? Se a discussão envolve uma das condições da ação penal, ela estará ausente ou presente - com o perdão da redundância - em todo o tipo de ação penal, independentemente da infração penal cometida.

Com isso, não haveria qualquer razão plausível para se criar, por parte do Conselho Nacional do Ministério Público, um limitador à possibilidade de concretização daquele acordo por parte dos membros do Ministério Público

\footnotetext{
72 GRINOVER, Ada Pellegrini. As Condições da Ação
} Penal. Ob. cit., p. 108. nacional. Essa limitação leva a um resultado indiscutível: a imposição de um conceito todo próprio e da abrangência do interesse de agir, sem sombra de dúvidas, configura-se uma atuação que extrapola não só a competência do Conselho Nacional do Ministério Público, mas também invade a seara da independência funcional, constitucionalmente protegida $\left(\S 1^{\circ}\right.$ do art. 129 $)^{73}$.

4.3 Um intento indevido de restrição à ação penal privada subsidiária da pública

Como se não fossem suficientes as máculas constitucionais já apontadas, o acordo de não-persecução penal, nos termos como atualmente regulado pela Resolução $\mathrm{n}^{\circ}$ 181/2017, também fere outra disposição constitucional, mas, agora, atingindo um direito fundamental consagrado na Carta de 1988. Referimo-nos ao direito de exercício da ação penal privada subsidiária da pública.

Já no direito romano do período imperial, verificava-se a existência de um mecanismo de controle sobre a inércia do legitimado primeiro para o ajuizamento da ação penal condenatória, caso ele não viesse a exercer esse direito. Segundo o Digesto de Justiniano, qualquer cidadão romano (accusatio iure extranei) passaria a possuir legitimidade ativa para o exercício da ação penal condenatória nos delitos de adultério - à época, considerados delitos públicos -, diante da omissão do marido ou do pai da adúltera em ajuizar a acusação no prazo de 60 dias contados do divórcio ${ }^{74}$.

Com isso, seja por sua origem histórica, seja pela forma como prevista em nossa Constituição Federal, a ação penal privada

\footnotetext{
${ }^{73}$ BRASIL. Governo Federal. Constituição Federal. Ob. cit.

${ }^{74}$ JUSTINIANO. El Digesto de Justiniano. 48, 5, 12, 10. Pamplona: Aranzadi, 1968. SANTALUCIA, Bernardo. Diritto e Processo Penale nell'Antica Roma. 2 ed. Milano: Giuffrè, 1998, p. 201-204.
} 
subsidiária da pública está assentada na premissa de que os legitimados ao seu exercício possuem o direito à busca da condenação de quem, em tese, praticou um fato tipificado como ilícito penal. E esse direito nasce a partir do momento em que, quem possui legitimidade ativa primária, não oferece sua acusação no prazo que a legislação fixa para tanto. Isso é o que prevê, aliás, o inciso LIX do artigo $5^{\circ}$ da Constituição Federal, ao dizer que: "será admitida ação privada nos crimes de ação pública, se esta não for intentada no prazo legal"75.

Essa soma de fatores aponta para outra inviabilidade jurídica intransponível do acordo de não-persecução penal, que é a existência da ação penal privada subsidiária da pública, manejável sempre que o Ministério Público deixa de se manifestar, no prazo fixado em lei, quanto ao destino da investigação criminal que lhe chega às mãos.

Por certo que o argumento a ser utilizado para afastar a incidência daquele mecanismo de controle sobre o Ministério Público é que não haveria ocorrido qualquer inércia de sua parte, quando da análise da investigação criminal. A formalização do acordo de não-persecução penal seria encarado pelo Ministério Público como um agir de sua parte, o que afastaria o pressuposto para o exercício da já referida ação penal privada.

$\mathrm{O}$ erro em tal argumento, no entanto, assenta-se no fato de pensar que toda e qualquer atuação do Ministério Público se mostra como impeditiva para o manejo daquele mecanismo de controle. Melhor explicando, há consenso que a ação penal privada subsidiária da pública não tem lugar quando o Ministério Público deixa de oferecer sua acusação, mas se manifesta na investigação criminal já concluída. Exemplos disso são: a) o requerimento de arquivamento; b) a requisição de diligências à autoridade policial;

${ }^{75}$ BRASIL. Governo Federal. Constituição Federal. Ob. cit. c) a complementação, por ele mesmo, da investigação criminal (artigo 47 do Código de Processo Penal); d) a indicação de incompetência do juízo; e e) a negativa de sua atribuição para atuar naquela investigação criminal.

Em que pese serem exatamente estas as posturas que o Ministério Público poderá vir a tomar, caso entenda não ser cabível o oferecimento da acusação, todas elas somente se justificam se estiverem legalmente embasadas. Ou seja, não há espaço para negativas de atuação, por parte do acusador público, além daquelas legalmente previstas em lei.

Um bom exemplo dessa limitação à negativa acusatória do Ministério Público pode ser encontrado em posição firmada por ninguém menos que o Supremo Tribunal Federal.

Bem sabemos que, ao receber os autos de um inquérito policial, o Ministério Público pode deixar de oferecer sua acusação se, dentro do prazo que a lei lhe concede, ele requisitar diligências à autoridade policial. É o que prevê o artigo 16 do Código de Processo Penal, ao dizer que: “O Ministério Público não poderá requerer a devolução do inquérito à autoridade policial, senão para novas diligências, imprescindíveis ao oferecimento da denúncia" ${ }^{, 76}$.

A palavra-chave, contudo, que autoriza o Ministério Público a não ajuizar sua acusação é imprescindíveis. Logo, não basta que o acusador público entenda que a investigação criminal que lhe foi apresentada esteja incompleta. De acordo com a legislação processual penal, é preciso que as informações que ele considere faltantes sejam um impeditivo intransponível ao ajuizamento da acusação, pois, caso elas não sejam um obstáculo ao oferecimento da denúncia, a ação deverá ser apresentada pelo Ministério Público.

É por isso que o Supremo Tribunal Federal deixou patente que não basta qualquer tipo de movimentação da investigação criminal, 
por parte do Ministério Público, para afastar a viabilidade do ajuizamento da ação penal privada subsidiária da pública. Na linguagem utilizada por aquela Corte, somente as diligências consideradas indispensáveis ${ }^{77}$ é que poderiam justificar a recusa do acusador público em oferecer sua ação penal. Do contrário, sua omissão acusatória passa a ser vista como um não agir ilegal, que, por certo, não pode impedir o exercício de um direito fundamental ao ajuizamento da ação penal privada subsidiária da pública.

Outra posição firmada pelo Supremo Tribunal Federal também parece soterrar a viabilidade do acordo de não-persecução penal, caso a pessoa legitimada a ajuizar a ação penal privada subsidiária da pública entenda em assim proceder.

Em julgado onde se reconheceu a condição de repercussão geral, aquela Corte fez a diferenciação entre movimentação externa e movimentação interna, quando realizadas pelo Ministério Público. Quanto à primeira, diria ela respeito à hipótese em que o Ministério Público deixaria de ajuizar sua ação penal, ao receber o inquérito policial, em razão de diligências requeridas ao Poder Judiciário ou requisitadas à polícia judiciária. Quanto à segunda, corresponderia à prática de diligências dentro da própria estrutura do Ministério Público. Assim, no caso das diligências internas, deveriam elas ser realizadas dentro do prazo que o Ministério Público tem para o oferecimento da acusação, pois a superação desse lapso não teria o condão de inviabilizar o ajuizamento da ação penal $\operatorname{privada}^{78}$.

${ }^{77}$ BRASIL. Supremo Tribunal Federal. Processual Penal.
Processo Penal. Habeas Corpus. Constrangimento ilegal.
Habeas Corpus $\mathrm{n}^{\circ}$ 74.276, Tribunal de Justiça do Estado do
Rio Grande do Sul, Brasília, 03 de setembro de 1996.
Disponível
http://redir.stf.jus.br/paginadorpub/paginador.jsp?docTP=
AC\&docID=619560. Acesso em: 10 out. 2017.
${ }^{78}$ BRASIL. Supremo Tribunal Federal. Processual Penal.
Repercussão Geral no Recurso Extraordinário com
Frente a essa posição do Supremo Tribunal Federal, sem grandes dificuldades podemos classificar o período de formalização do acordo de não-persecução penal e o tempo destinado ao seu cumprimento como sendo aquelas diligências internas. Isso porque, a investigação criminal seguirá com o Ministério Público após a superação do prazo legal para o oferecimento da ação penal pública, pois o eventual não cumprimento do acordo se configura em condição para o ajuizamento de sua acusação. Ou seja, o Ministério Público ficaria no aguardo de um ocasional não cumprimento do acordo para ajuizar sua acusação - período, aqui, equiparado a diligências internas -, mas essa espera não impediria o exercício do mecanismo de controle sobre sua inércia, que foi entregue às pessoas legitimadas ao exercício da ação penal privada subsidiária da pública.

Enfim, também por essa razão, não haveria como prosperar o acordo criado pela Resolução nº 181/2017.

\section{CONCLUSÃO}

Um dos caminhos encontrados no direito comparado, para dar conta do aumento da demanda na esfera criminal, foi a ampliação das formas de autocomposição de conflitos entre o acusador público e a pessoa que figura como sujeito passivo de persecução criminal. Por isso, era uma questão de tempo que essa discussão também chegasse ao Brasil, de modo a buscar o alargamento daquelas hipóteses de acordo já presentes em nossa legislação.

O Conselho Nacional do Ministério Público procurou inserir em nosso país o acordo de não-persecução penal, justificando-o com

Agravo. Repercussão Geral no Recurso Extraordinário com Agravo $\mathrm{n}^{\circ}$ 859.251, do Tribunal de Justiça do Distrito Federal, Brasília, 14 de maio de 2015. Disponível em: http://redir.stf.jus.br/paginadorpub/paginador.jsp?docTP=T P\&docID=8522862. Acesso em: 10 out. 2017. 
base em uma realidade verificada no direito alemão, bem como, sob a invocação de argumentos de ordem sistêmica (adoção constitucional do sistema acusatório) e vinculados à teoria geral do processo. Entretanto, nenhum dos argumentos apresentados por aquele Conselho conseguem se manter íntegros, após um confronto com suas bases teóricas e de direito comparado, o que nos leva a apontar um provável insucesso daquele novel instituto, quando de sua análise mais detida por parte de nossos Tribunais Superiores.
Mesmo assim, o futuro do acordo de não-persecução penal não invalida a abertura de um grande e franco debate sobre a otimização da persecução penal brasileira. Entretanto, o caminho mais correto a ser seguido é a busca de sua inserção, seja em que moldes forem, pela via legislativa, e motivando a abertura do devido processo legal. Só assim se estará preservando um texto que procura conjugar e proteger os interesses da sociedade como um todo: a nossa Constituição

Federal.

\section{REFERÊNCIAS}

ALEMANHA. BVerfG, 2 BvR 2628/10, 2 BvR 2883/10 und BvR 2155/11, vom 19.3.2013. Berlin: Bundesverfassungsgericht, 2013, documento não paginado. Disponível em: http://www.bverfg.de/entscheidungen/rs20130319_2bvr262810.html. Acesso em: 24 ago. 2013.

. The German code of criminal procedure (StPO). Code of Criminal Procedure in the version published on 7 April 1987 (Federal Law Gazette [Bundesgesetzblatt] Part I p. 1074, 1319), as most recently amended by Artcile 3 of the Act of 23 April 2014 (Federal Law Gazette Part I p. 410). Disponível em: https://www.gesetze-im-internet.de/englisch_stpo/. Acesso em: 13 out. 2017.

ALTENHAIN, Karsten. Absprachen in german criminal trials. In: THAMAN, Stephen C. (Org.). World plea bargaining: consensual procedures and the avoidance of the full criminal trial. Durham: Carolina Academic Press, 2010.

ANDRADE, Mauro Fonseca. Ministério Público e sua Investigação Criminal. Porto Alegre: Fundação Escola Superior do Ministério Público do Rio Grande do Sul, 2001.

ANDRADE, Mauro Fonseca. Sistemas Processuais Penais e seus Princípios Reitores. 2 ed. Curitiba: Juruá, 2013.

BOSCHI, Marcus Vinicius. Ação, Pretensão e Processo Penal. Teoria da Acusação. Porto Alegre: Livraria do Advogado, 2015.

BRANDALISE, Rodrigo da Silva. Justiça penal negociada. Negociação de sentença criminal e princípios processuais penais relevantes. Curitiba: Juruá, 2016.

BRASIL. Câmara dos Deputados. Projeto de Lei $\mathrm{n}^{\mathrm{o}}$ 8.045, de 2010. Disponível em: http://www.camara.gov.br/proposicoesWeb/fichadetramitacao?idProposicao=490267. Acesso em: 10 out. 2017.

Conselho Nacional do Ministério Público. Pronunciamento Final em Procedimento de Estudos. Disponível em: http://www.cnmp.mp.br/portal/images/Pronunciamento_final.pdf. Acesso em: 10 out. 2017.

. Conselho Nacional do Ministério Público. Procedimento de Estudos e Pesquisas 01. Despacho inaugural. Disponível em: http://www.cnmp.mp.br/portal/images/Despacho_inaugural_-_PEP_01-2017.pdf. Acesso em: 10 out. 2017 
Conselho Nacional do Ministério Público. Reclamação para Preservação da Competência e da Autoridade das Decisões do Conselho. Decisão Liminar, Brasília, 02 de outubro de 2017. Disponível em: https://iarioeletronico.cnmp.mp.br/apex/EDIARIO.view_caderno?p_id=2964. Acesso em: 10 out. 2017.

Conselho Nacional do Ministério Público. Resolução 181. Disponível em: https://diarioeletronico.cnmp.mp.br/apex/EDIARIO.view_caderno?p_id=2964. Acessado em: 10 out. 2017.

Governo Federal. Código de Processo Penal. Disponível em: http://www.planalto.gov.br/ccivil_03/decretolei/Del3689Compilado.htm. Acesso em: 10 out. 2017.

Governo Federal. Constituição Federal. Disponível em: http://www.planalto.gov.br/ccivil_03/constituicao/constituicao.htm. Acesso em: 10 out. 2017.

Superior Tribunal de Justiça. Processo Penal. Recurso em Habeas Corpus $\mathrm{n}^{\circ}$ 85.101, Brasília, 15 de agosto de 2017.

Disponível

em: https://ww2.stj.jus.br/processo/revista/documento/mediado/?componente=ITA\&sequencial=1623769\&num_registro= 201701277234\&data=20170821\&formato=PDF. Acesso em: 10 out. 2017.

Supremo Tribunal Federal. Direito Administrativo. Direito Civil. Medida Cautelar em Ação Declaratória de Constitucionalidade $\mathrm{n}^{\mathrm{o}}$ 12, Brasília, 16 de fevereiro de 2006. Disponível em: http://redir.stf.jus.br/paginadorpub/paginador.jsp?docTP=AC\&docID=372910. Acesso em: 10 out. 2017.

. Supremo Tribunal Federal. Direito Constitucional. Execução Penal. Arguição de Descumprimento de Preceito Fundamental $\mathrm{n}^{\mathrm{o}}$ 347, Brasília, 09 de setembro de 2015. Disponível em: http://redir.stf.jus.br/paginadorpub/paginador.jsp?docTP=TP\&docID=10300665. Acesso em: 10 out. 2017.

. Supremo Tribunal Federal. Direito Constitucional. Mandado de Segurança n ${ }^{\circ} 27621$, do Conselho Nacional de Justiça, Brasília, 07 de dezembro de 2011. Disponível em: http://redir.stf.jus.br/paginadorpub/paginador.jsp?docTP=TP\&docID=1983588. Acesso em: 10 out. 2017.

Supremo Tribunal Federal. Direito Eleitoral. Processo Penal. Medida Cautelar em Ação Direta de Inconstitucionalidade $\mathrm{n}^{\mathrm{o}}$ 5104, Brasília, 21 de maio de 2014. Disponível em: http://redir.stf.jus.br/paginadorpub/paginador.jsp?docTP=TP\&docID=7088758. Acesso em: 10 out. 2017.

Supremo Tribunal Federal. Processo Penal. Ação Direta de Inconstitucionalidade. Ação Direta de Inconstitucionalidade $\mathrm{n}^{\circ}$ 5790, Brasília, 06 de outubro de 2017. Disponível em: http://www.stf.jus.br/portal/processo/verProcessoAndamento.asp. Acesso em: 10 out. 2017.

Supremo Tribunal Federal. Processo Penal. Ação Direta de Inconstitucionalidade. Ação Direta de Inconstitucionalidade $\mathrm{n}^{\mathrm{o}}$ 57930, Brasília, 13 de outubro de 2017. Disponível em: http://www.stf.jus.br/portal/processo/verProcessoAndamento.asp?incidente=5288159. Acesso em: 13 out. 2017.

Supremo Tribunal Federal. Processo Penal. Ação Direta de Inconstitucionalidade. Ação Direta de Inconstitucionalidade $\mathrm{n}^{\mathrm{o}}$ 2970, Brasilia, 20 de abril de 2006. Disponível em: http://redir.stf.jus.br/paginadorpub/paginador.jsp?docTP=AC\&docID=266970. Acesso em: 10 out. 2017.

Supremo Tribunal Federal. Processo Penal. Recurso em Habeas Corpus. Constrangimento ilegal. Recurso em Habeas Corpus n ${ }^{\circ}$ 48.728, do Tribunal de Justiça do Estado de São Paulo, Brasília, 26 de maio de 1971. Disponível em: http://redir.stf.jus.br/paginadorpub/paginador.jsp?docTP=AC\&docID=93199. Acesso em: 10 out. 2017. 
Supremo Tribunal Federal. Processo Penal. Recurso Extraordinário. Recurso Extraordinário no 593.727 , do Tribunal de Justiça do Estado de Minas Gerais, Brasília, 14 de maio de 2015. Disponível em: http://redir.stf.jus.br/paginadorpub/paginador.jsp?docTP=TP\&docID=9336233. Acesso em: 10 out. 2017.

Supremo Tribunal Federal. Processual Penal. Processo Penal. Habeas Corpus. Constrangimento ilegal. Habeas Corpus n ${ }^{\circ}$ 74.276, Tribunal de Justiça do Estado do Rio Grande do Sul, Brasília, 03 de setembro de 1996. Disponível em: http://redir.stf.jus.br/paginadorpub/paginador.jsp?docTP=AC\&docID=619560. Acesso em: 10 out. 2017.

Supremo Tribunal Federal. Processual Penal. Repercussão Geral no Recurso Extraordinário com Agravo. Repercussão Geral no Recurso Extraordinário com Agravo no 859.251, do Tribunal de Justiça do Distrito Federal, Brasilia, 14 de maio de 2015.2 Disponível http://redir.stf.jus.br/paginadorpub/paginador.jsp?docTP=TP\&docID=8522862. Acesso em: 10 out. 2017.

CABRAL, Rodrigo Leite Ferreira. O acordo de não-persecução penal criado pela nova Resolução do CNMP. CONAMP: Brasília, 2017, documento não paginado. Disponível em: https://www.conamp.org.br/pt/biblioteca/artigos/item/1783-o-acordo-de-nao-persecucao-penalcriado-pela-nova-resolucao-do-cnmp.html?utm_campaign=artigo_o_acordo_de_naopersecucao_penal_criado_pela_nova_resolucao_do_cnmp\&utm_medium $=$ email $\& u t m \_s o u r c e=R D+S$ tation. Acesso em: 25 set. 2017.

COSTA, Paula Bajer Fernández Martins da. Ação Penal Condenatória. São Paulo: Saraiva, 1995.

COUTINHO, Jacinto Nelson de Miranda. Sistema Acusatório. Cada parte no lugar constitucionalmente demarcado. Revista de Informação Legislativa, Brasília, v. 183, p. 103-116, jul./set. 2009.

DEZEM, Guilherme Madeira. Curso de Processo Penal.3. ed. São Paulo: RT, 2017.

JUSTINIANO. El Digesto de Justiniano. Pamplona: Aranzadi, 1968.

GRINOVER, Ada Pellegrini. As Condições da Ação Penal. São Paulo: José Bushatsky, 1977. . Liberdades Públicas e Processo Penal (as interceptações telefônicas). 2. ed. São Paulo: RT, 1982.

KOBOR, Susanne. Bargaining in the criminal justice systems of the United States and Germany: matter of justice and administrative efficiency within legal. Frankfurt am Main: Internationaler Verlag der Wissenschaften, 2008.

LANGER, Máximo. From legal transplants to legal translations: the globalization of plea bargaining and the americanization thesis in criminal procedure. In: THAMAN, Stephen C. (Org). World plea bargaining: consensual procedures and the avoidance of the full criminal trial. Durham: Carolina Academic Press, 2010.

LIMA, Marcellus Polastri. Curso de Processo Penal. 9. ed. Brasília: Gazeta Jurídica, 2016.

LOPES JÚNIOR, Aury. (Re)Pensando as condições da Ação Processual Penal. In: GAUER, Ruth Maria Chittó (Org.). Criminologia e Sistemas Jurídico-Penais Contemporâneos. Porto Alegre: EdiPUCRS, p. 277-306, 2008.

. Direito Processual Penal. 13. ed. São Paulo: Saraiva, 2016. 
NUCCI, Guilherme de Souza. Manual de Processo Penal e Execução Penal. 13. ed. Rio de Janeiro: forense, 2016.

OLIVEIRA, Eugênio Pacelli de. Curso de Processo Penal. 20. ed. São Paulo: Atlas, 2016.

PORTUGAL. Constituição da República Portuguesa. Lisboa: Procuradoria-Geral Distrital de Lisboa. Disponível em: http://www.pgdlisboa.pt/leis/lei_mostra_articulado.php?nid=4\&tabela=leis. Acesso em: 13 out. 2017.

Decreto-Lei $\mathrm{n}^{\circ}$ 78/87, de 17 de fevereiro de 1987. Aprova o código do processo penal. Disponível em: http://www.pgdlisboa.pt/leis/lei_mostra_articulado.php?nid=199\&tabela=leis. Acesso em: 13 out. 2017.

. Procuradoria-Geral da República. Directiva no 02/2014, de 21 de fevereiro de 2014. Lisboa: PGR, 2014. Disponível em: http://www.ministeriopublico.pt/iframe/diretivas. Acesso em: 13 out. 2017.

. Procuradoria-Geral Distrital de Coimbra. Memorando de 19 de janeiro de 2012. Justiça negociada: acordos sobre a sentença em processo penal. Coimbra: Procuradoria-Geral Distrital, 2012. Disponível em: http://www.oa.pt/up1/\%7Bee0e9275-cf60-4420-a2f4-840bd0c0bb2b\%7D.pdf. Acesso em: 13 out. 2017.

Procuradoria-Geral Distrital de Lisboa. Orientação no 01/2012, de 13 de janeiro de 2012. Procuradora-Geral Distrital Francisca Van Dunem emite uma orientação aos magistrados do MP do Distrito em sentido favorável a realização de acordos sobre a sentença em processo penal. Lisboa: Conselho Distrital do Porto da Ordem dos Advogados, 2011. Disponível em: http://www.pgdlisboa.pt/docpgd/doc_mostra_doc.php?nid=153\&doc=files/doc_0153.html . Acesso em: 13 out. 2017.
2013.
. Supremo Tribunal de Justiça. Processo no 224/06.7GAVZL.C1.S1. Lisboa, 10 de abril de http://www.dgsi.pt/jstj.nsf/954f0ce6ad9dd8b980256b5f003fa814/533bc8aa516702b980257b4e00328 1f0?OpenDocument. Acesso em: 13 out. 2017.

SANTALUCIA, Bernardo. Diritto e Processo Penale nell'Antica Roma. 2 ed. Milano: Giuffrè, 1998

SANTIN, Valter Foleto. O Ministério Público na investigação criminal. Bauru: Edipro, 2001.

SILVEIRA, Marco Aurélio Nunes da. As Condições da Ação no Direito Processual Penal. Sobre a Inadequação das Condições da Ação Processual Civil ao Juízo de Admissibilidade da Acusação. Florianópolis: Empório do Direito, 2016.

VIEIRA, Guilherme Siqueira. Poder Investigatório do Ministério Público: Apontamentos sobre a Necessidade de regulamentação. Revista Magister de Direito Penal e Processual Penal, São Paulo, n. 71, p. 14-32, abr./maio 2016.

WEIGEND, Thomas; TURNER, Jenia Iontcheva. The constitutionality of negotiated criminal judgments in Germany. German Law Journal, Lexington, v. 15, n. 1, p. 81-106, feb. 2014. Disponível em http://www.germanlawjournal.com/pdfs/FullIssues/GLJ\%20Vol\%2015\%20No\%201\%20Full\%20Iss ue.pdf. Acesso em: 03 set. 2017. 
ZIESEMER, Henrique da Rosa. Direito Institucional. Comentários ao Regimento Interno do Conselho Nacional do Ministério Público. 2. ed. Rio de Janeiro: Lumen Juris, 2017.

Recebido em: 19/10/2017

Aceito em: 10/12/2017 
